\title{
Petroleum - depleting reserves, rising prices and the unfolding energy crisis
}

\author{
Ananda Gunatilaka* \\ 10, Thumbovila, Piliyandala.
}

\begin{abstract}
Oil accounts for more than $50 \%$ of the world's energy requirements; oil and gas together supply almost $70 \%$. About $65 \%$ of the oil is used for transportation in an increasingly mobile world. A major crisis in the supply of these commodities can drastically affect the price and bring modern society to a standstill. Supply problems have everything to do with rising demand (increasing at 2 to $3 \%$ per annum), regional and global events and now production peaks. Countries that have access to fuel resources and supplies are naturally the most technologically, economically and financially powerful on the world stage. Spiraling oil prices (as we are witnessing now) will result in economic recession and currency inflation, eventually destabilizing the world's economies. Consequently, energy security should be a primary responsibility of mainstream governance across the world. We have already burnt off half the world's oil and gas reserves. The oil industry has reached its production peak and will soon start the expected decline. Energy experts indicate that oil will run out in about 40 years and natural gas in about 60 years - a frightening prospect for the world's economies. How the stakeholders respond to this impending crisis and cooperate in managing the decline will determine the future direction and stability of world economies. Conservation is the best short term solution to the crisis. Energy alternatives and renewable sources are still very marginal and require a long lag time to come on stream. Countries will have to choose an energy mix that suits them best in the future. The era of cheap oil has ended.
\end{abstract}

Key words: Energy crisis, oil \& gas depletion, oil prices, peak oil, $\mathrm{R} / \mathrm{P}$ ratio

\section{INTRODUCTION}

Fifty years after the first oil well was drilled in 1859 , oil and gas was beginning to displace coal as the fuel of choice. They burned more cleanly and could be transported by pipelines, ship or rail. Yet, about half of the energy produced is lost in distribution, wastage and inefficient use. It is well to remember that these fossil fuels which have been locked up in the rocks for millions of years are being extracted today at such a rate that in less than 250 years we would have depleted them totally and of course they are non-renewable. We use them up much faster than the geological processes that produce them.

How much petroleum resources and reserves (oil and gas) are left in the rocks? How long will they last? Reserves are deposits that have already been discovered, proven or known and can be extracted economically and legally at the present time. Resources refer to the total quantity of petroleum that may eventually become available for use. Resources include reserves plus discovered deposits that are too poor in quantity or quality to be economically extractable now or are technologically difficult to mine and must await better technology and/or higher prices before they can be profitably mined, plus undiscovered deposits that await geological discovery. As conditions change, some resources become reserves and vice versa.

As this article is being written, the price of crude oil reached an all time high of US $\$ 75$ per barrel - a rise of US\$ 15 in two months. Two years ago it was US\$33. Price wise, it is probably the most volatile commodity in the world. It is not only a question of providing fuel for transportation, power generation and domestic heating. By-products of the petroleum industry are major ingredients in plastics, synthetic fibres, dyes, cosmetics, pharmaceuticals, explosives, fertilizers, records, tapes, compact discs etc. It is also refined to produce propane for stoves, kerosene, motor oil, lubricants and gasoline for cars, tyres, tar and asphalt for roads. Modern society is helpless without it. For those countries with no fossil fuels and a per capita income of < US\$1000, the cost of oil is prohibitive with attendant subsidies. They will be dependent on aid handouts, loans and international financial institutions for their survival with debt servicing becoming a permanent burden on economic growth. 
This article presents an overview of the impending energy crisis as oil and gas reserves in the world are now in depletion and expected to run out in $\sim 40$ and 60 years respectively. ${ }^{1-10}$

\section{World oil reserves - how much and where?}

The total recoverable conventional oil discovered in the world was about 2013 billion barrels (Bb); up to the end of 2005 , about $1065 \mathrm{Bb}\left(1.6 \times 10^{11} \mathrm{~m}^{3}\right)$ has been produced and burnt (exactly half). ${ }^{2}$ Of the rest, $\sim 700$ $\mathrm{Bb}$ is in the Middle East-Arabian-Persian Gulf region, which is about $70 \%$ of the known recoverable reserves. Saudi Arabia, Iran, Iraq, Kuwait and the UAE possess nearly $60 \%$ of the reserves. North America accounts for 8 per cent, Central and Southern America 7\%, Eastern Europe 6\%, Western Europe 1\%, Africa $\sim 6 \%$, Australasia $4 \%$. Total OPEC (Organization of Petroleum Exporting Countries) producers account for $80 \%$ of the proven reserves, OECD (Organization for Economic Co-operation and Development) $10 \%$ and the rest are non-OPEC producers. Of the 700 odd petroleum basins, about $95 \%$ of the world's known oil occurs in only 50 basins; $75 \%$ in only 10 of them. ${ }^{3}$ The most prolific of these is the Arabian-Persian Gulf Basin. New basins were discovered in Central Asia-Caspian Sea region and elsewhere, but this would not alter the existing picture.

It seems a law of nature that the size of any population follows a lognormal distribution. This is so for mineral deposits, magnitude of earthquakes, income levels of a country and the periodic table (only 8 elements make up more than $1 \%$ of the crust each, by weight; $O$ and Si make up 75\%; only ten elements make up $99 \%$ ). So it is for petroleum basins (95\% of oil in only 50 basins). This lognormal distribution means that a giant $\left(500 \times 10^{6} \mathrm{Bb}\right.$ of oil) or supergiant oilfield $\left(5 \times 10^{9} \mathrm{Bb}\right)$ discovery overshadows the hundreds of average discoveries. ${ }^{2}$ Most of the giants were discovered before 1970. Between 1955 and 1970 was the peak, with fifty $150 \mathrm{Bb}$ fields discovered. There has been a marked decline in annual rate of additions to world reserves since 1970. Around the mid 1960s, new discoveries peaked and world oil production overtook the growth of new reserves soon after and today we are using up 4 barrels for every new barrel discovered. That oil was a fast depleting and non-renewable resource was not taken seriously and unrealistic optimism prevailed in the world oil industry. Discoveries of ordinary oilfields continued to soar, but hardly made a dent to the emerging scenario.

The cost of finding a new oilfield is calculated in billions of dollars. It takes 7 to 20 years to see a return on upfront investments required for hydrocarbon exploration. The cost of finding a new barrel of oil is $\sim 10$ US cents to Kuwait and Saudi Arabia; it is more than US\$ 4 dollars in the USA and elsewhere. Production costs are US\$1.50 / b in Saudi Arabia; about US\$ 5 globally and as high as US\$ 10 elsewhere. The Arabian-Persian Gulf has the lowest oil finding and lifting costs. These costs need to be seen in the context of OPEC, which have about $80 \%$ of the proven oil reserves and account for $40 \%$ of the production. NonOPEC countries have the largest refining capacity $(60 \%)$ of world oil production.

\section{The $\mathrm{R} / \mathrm{P}$ ratio and the concept of peak oil}

American geologist, King Hubbert over 50 years ago proposed that the rate of new oil discoveries depends on the fraction of oil that has not yet been discovered. Similarly, the rate of oil production depends on the fraction of oil that has not yet been produced. Hubbert developed a mathematical model of petroleum extraction, which predicted that the rate of extraction over time would follow a logistic curve ${ }^{2}$. This implies that the predicted rate of oil extraction at any given time would be shown by the value of the logistic curve at that time. The curve follows a bell-shaped pattern now called the Hubbert curve (Figure 1). It shows, at first, a slow, steady increase in production, then a sharp increase followed by a plateau or "the peak" and finally a steep decline. The maximum output point is called the "peak". Hubbert postulated that the world oil production rate peaks when half of the proven oil reserves have been extracted. After the peak, production slowly tapers off and at some point it takes more energy to recover the remaining oil than the energy contained in them. At that point, the oilfield is abandoned. Hubbert accurately predicted that in the USA the peak would occur in 1971 and that US oil would be exhausted around 2000 . This model would apply only to a theoretical, unconstrained oil province, without political or environmental factors in play. In 1997,

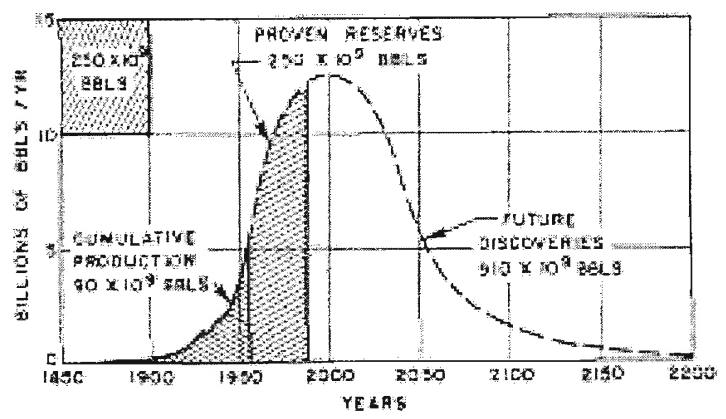

Figure 1: The original Hubbert curve of petroleum depletion and the concept of peak oil. 


\section{OIL AND GAS LIQUIDS}

\section{Scenario}

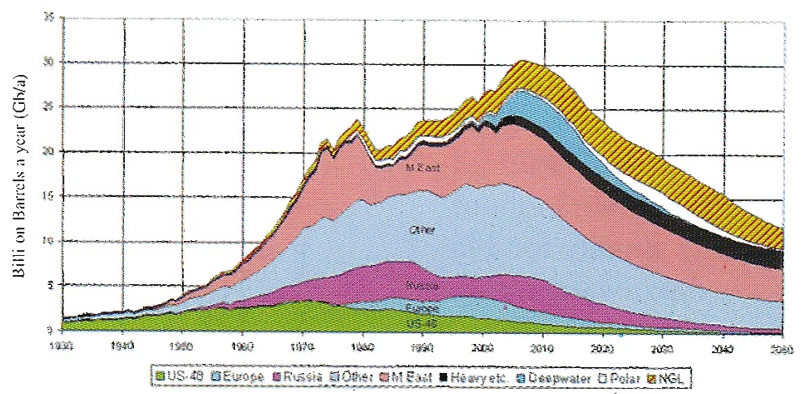

Figure 2: World oil and gas depletion scenario in 2004 and peak oil estimates according to Campbell.,12

geologist Craig Hatfield calculated that even if global oil consumption remained steady, worldwide oil production would go into absolute decline by $2036 .{ }^{4}$ But consumption keeps going up, increasing from 60 $\mathrm{mb} / \mathrm{d}$ in 1985 to $69 \mathrm{mb} / \mathrm{d}$ in 1995 to $85 \mathrm{mb} / \mathrm{d}$ in 2005 (British Petroleum Energy Review ${ }^{5}$ ). Hatfield's date for peak oil production is 2011 .

These calculations are based on the well known $R / P$ ratio of the oil industry $(R=$ reserves; $P=$ daily production of oil). ${ }^{1,5}$ The ratio is calculated for every oil producing country and it gives the number of years of oil production left. $\mathrm{R} / \mathrm{P}$ varies from 19 years in North America; 42 for South and Central America (Mexico); 7 for Western Europe; 22 for Eastern Europe; 95 for the Middle East; 25 for Africa; 17 for total Asia and Australasia; 15 for OECD; 80 for OPEC and 16 for nonOPEC countries. The current estimate for the whole world is 36 years. ${ }^{5}$ Dr. Colin Campbell, an expert on peak oil, using the most complete data set on petroleum statistics (Petroconsultants / IHS, Geneva) made a comprehensive analysis on peak oil (Figure 2). ${ }^{6}$ Rather than using the $R / P$ ratio, he factored in maximum oil production statistics for each country. His statistical analysis resulted in a peak oil date of 2010 . Predictions have been improved by time-shifting the discovery curve to match the production curve (Figure 3). ${ }^{7}$ Professor Kenneth Deffeyes of Princeton University, USA, who has been tracking world reserves and production for decades, after modelling and analysis of over 100 years of oil industry statistics, announced his historical date of peak oil (Figure 4). On the $16^{\text {th }}$ of December 2005 the world's proven reserves of oil reached half its known volume $(\sim 1065 \mathrm{Bb})$ in the rocks. Peak oil is the middle point of oil depletion; it follows from the Hubbert Peak Theory. ${ }^{8-12}$ Peak oil being a plateau will last for a few years, before the inevitable decline. The various depletion scenarios are given in Figure $5 .{ }^{8}$

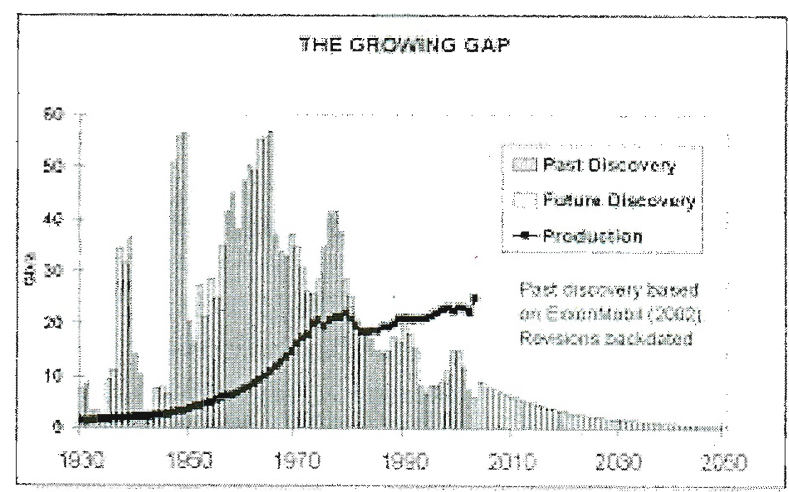

Figure 3: Graph showing relationship of oil discoveries and oil production rates over time. Note that discoveries peaked prior to 1970. The large shortfall between current production and future reserves is the impending oil crisis - as the gap continues to widen. $\mathrm{Gb} / \mathrm{a}=$ gigabarrels per annum

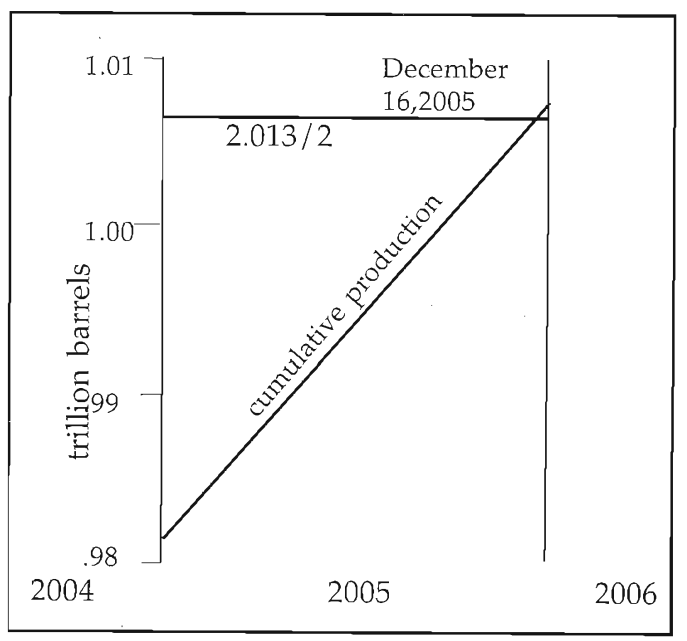

Figure 4: Peak oil scenario according to Deffeyes. Total cumulative oil production exceeded the mid point of oil reserves on $16^{\text {th }}$ December 2005. Only the last two years, data is shown. www.princeton.edu/hubbert/. 
Around 37 of the 50 major oil producer countries are in decline, having passed the mid point of oil reserves years ago. ${ }^{5-12}$ The ongoing global oil decline cannot be reversed by new discoveries (Figure 3). There is nothing on the horizon to turn things around for the annual 1.7 trillion dollar industry. Since 1985, each year's newly discovered oil reserves have amounted to only $40 \%$ of that year's global consumption. Now it is down to about $25 \%$. Global oil production after rising steadily for 145 years has peaked and will be on a downward trend. Today, the peak daily production is around $85 \mathrm{Mb}(30$ $\mathrm{Bb} / \mathrm{annum}$ ) of which the USA accounts for $25 \%$ of the world consumption. ${ }^{5}$ In another 25 years, oil production could be down to half this amount. With a $2-3 \%$ increase in annual demand (mainly from China, India, Japan, Korea and Taiwan) the supply side is being stretched to the limit. Iran is the fourth largest producer of crude oil $(\sim 4 \mathrm{Mb} / \mathrm{d})$. If there is an embargo over the nuclear issue, a severe worldwide recession is possible, keeping in mind that $20 \%$ of the world's oil $(\sim 15-20 \mathrm{Mb} / \mathrm{d})$ and gas pass through the narrow and shallow Hormuz Straits between Iran and Oman. The strategic implications are obvious. A drop in supply of $2 \mathrm{Mb} / \mathrm{d}$ is enough to cause disruption and prices will soar (as during the Iran -Iraq war). OPEC is now producing at "maximum output". Saudi Aramco, the world's largest single producer ( 9.15 $\mathrm{Mb} / \mathrm{d}$ in 2005) has announced that it is now producing
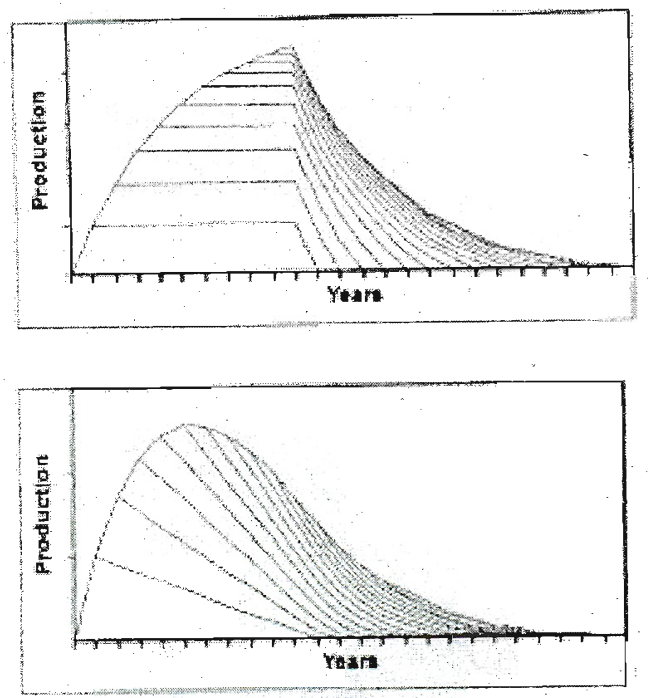

Figure 5: Theoretical models of production output from a group of oil and gas fields with the assumption that larger fields are found earlier and new discoveries have a negligible impact on reserves. ${ }^{8}$ Upper graph- field production shows a trapezoidal profile more typical of gas fields. Lower graph-field productions show profiles typical of oil fields (rapid build-up followed by slow decline). at maximum capacity. An increase on this figure will only come at risk of damage to the oil reservoirs and increasing water with the oil.

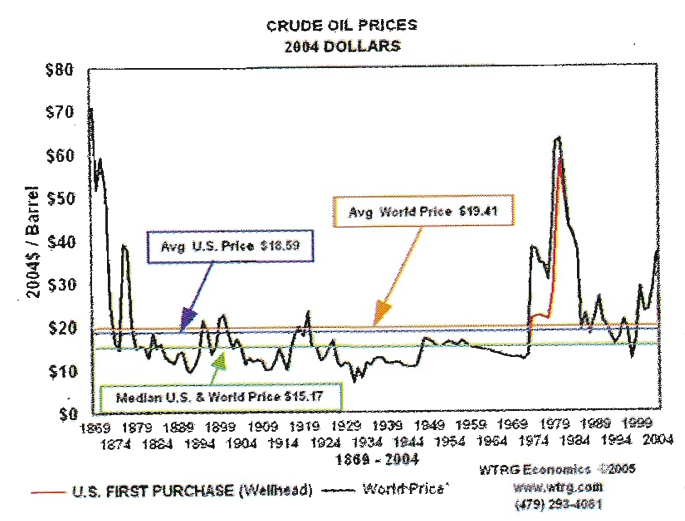

Figure 6: Historical record of crude oil prices adjusted for inflation and based un 2act values. Sce wext for discussion. Courtesy of WTRG Economics.

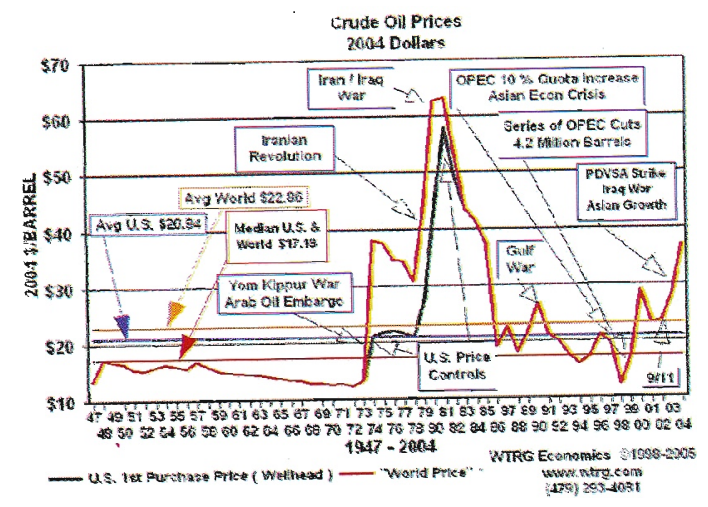

Figure 7: Response of crude oil prices to major world and regional events, which affected supply and caused price rises. The biggest impact on the oil price was the Iran-Iraq War in 1979-1981 (the third and fourth largest oil producers who can pump $10 \mathrm{Mb} / \mathrm{d}$ between them). See text for discussion. Courtesy of WTRG Economics

\section{The price of oil}

Ultimately, like any other commodity, it is supply and demand that will determine the price of oil. With only 36 years of reserves and increasing demand, prices will be supersensitive to shortfalls with wild price swings. The historical record of oil price fluctuations is given in Figures 6 and 7. Note the influence of major world and regional events on the price, when the demandsupply equation is disrupted. There are several ways of looking at the emerging crisis. Figure 6 shows that, historically, the price of oil has not increased too much in real terms if inflation is taken into account. In the 
post World War II era, the median and adjusted world price of crude oil was US $\$ 17 / \mathrm{b}$ at 2004 base prices, which means that only $50 \%$ of the time from 1947 to 2004 have oil prices exceeded this value. In March 2000, a US\$22-US\$ 28 price band was adopted for OPEC crude. Before that, oil exceeded US\$23/b only in response to war and conflict in the Middle East. Since 1869, world prices adjusted for inflation have averaged US $\$ 19.41 / b$. We have had it very cheap for a very long time. US $\$$ dollars $75 / \mathrm{b}$ would certainly impact on the global economy. This would cause worry if the world was in an economic recession; but with over $4 \%$ growth per annum, the global economy should be able to cope if certain structural adjustments are in place to conserve and curtail profligacy.

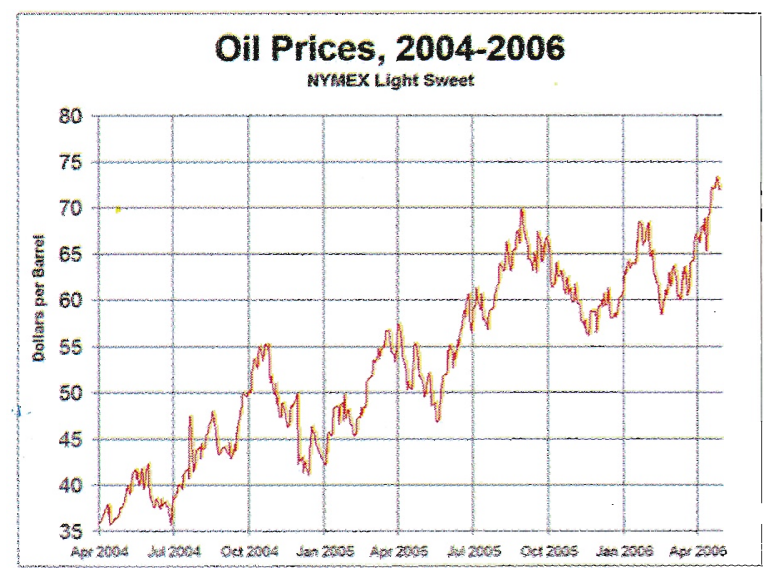

Figure 8: Oil price rise over the past two years, which has more than doubled. (courtesy Wikipedia).

Economists can advise whether it is better to have oil at US\$ 75 with 5 to $6 \%$ economic growth or 2 to $3 \%$ growth at US\$ 55 per barrel, provided interest rates remain low and steady. What are unacceptable to growing economies are high oil prices with high interest rates. Rising energy prices sets off chain reactions in the global economies, with rising inflation, high manufacturing costs, weaker currencies, high costs of consumer products, high Current Account Deficits (CAD) and debt repayments for poorer nations, followed by recessions etc. High energy costs account for $>50 \%$ of the CAD of many nations (World Bank). Three of the last four global recessions were caused by sharp rises in oil price (Figures 6, 7).

The current price rise to US $\$ 75$ has nothing to do with peak oil. It has everything to do with surging demand from India, China, Russia, Brazil and Korea etc. (close to 3 billion total populations) as they annually lift large sections of their populations into the middle- classes. Middle classes want to drive cars, build better houses, run air-conditioners, holiday abroad, gadgetry, computers, TVs, DVDs, CDs, cell phones and all other paraphernalia of conspicuous consumption. All of this has grave implications for total energy consumption. Here we are talking of 300 to 400 million people in the new middle-class. For the next 25 years at most, cars will have to run on some form of refined oil. The problem is that there are so many of them with these expectations. By this time, China and India will probably have more cars than in the USA; Brazil and Russia more than Japan. If it goes on uncontrolled, we may be heading for a billion automobile world scenario. What price oil then? Are these rational expectations? This is perhaps the very first time that a soaring oil price has been caused by surging demand rather than some contrived or forced political event (Figure 8). Unrest in Nigeria's oil producing region (which suddenly removed $\sim 500,000$ $\mathrm{b} / \mathrm{d}$ ) and the Iranian crisis added to the price rise, doubling from February 2004 to April 2006.

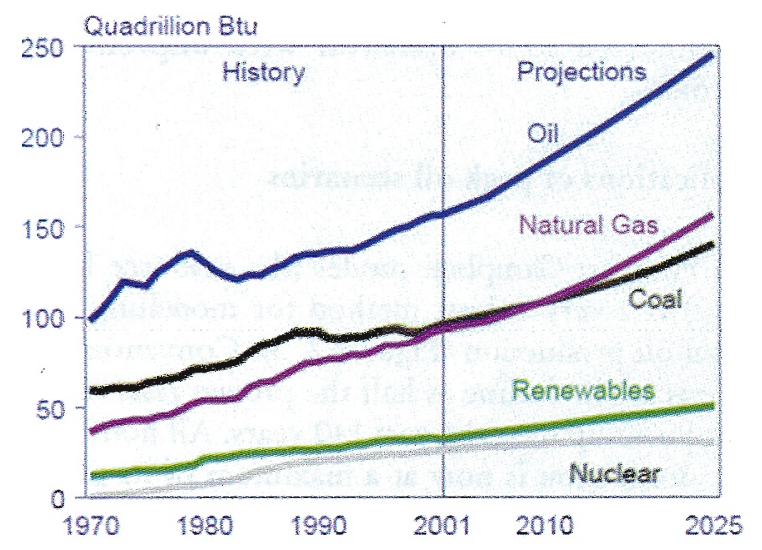

Figure 9: World energy consumption from different sources. Note the projected slow rate of development of renewables. One quad $=10^{15} \mathrm{btu}$.

In another 5 years, oil will go over US\$ 100 per barrel, perhaps to US $\$ 125$. But what if it doubles again in two years? More than $99 \%$ of the energy consumers would not have even heard of peak oil and the dwindling supplies to come. With enforced protocols on gas emissions and global warming, we will face more constraints. This is a good situation to be in. Governments, oil companies and society will then think of conservation (the best additional source of energy) and other energy options seriously. It is wise not to believe in what the oil producers and oil companies say on this issue - that oil reserves are ample for current consumption for the coming decades. But they will say so even if it is not true. 
An aggressive response to the impending crisis will require strong political will. Governments must do all it can to ensure energy security and sustainable growth. Any realistic economic planning must assume that in another 5 years the oil price will be $>$ US $\$ 100$ per barrel. All what we can hope for is a steady rise in the price over time and not a sharp shock of doubling prices. Wild price fluctuations, with gluts and shortfalls are probably over. For sure, the era of cheap oil is finally over. There is a high hidden cost to cheap oil. This is the military protection of supplies. The USA spends US $\$ 100$ billion per year to ensure free flow of oil from oil-rich unstable regions, which is indirectly subsidized by the taxpayers of consuming countries. The real cost to the US economy could be as high as US\$10 per gallon. The low retail price of oil and gas gave a competitive market advantage over alternative energy mixes. Since the oil market is dominated by OPEC, the short term price of oil will be controlled by the cartel and the oligopoly of oil companies (Figure 8). Oil is currently traded in US dollars. If OPEC decides to shift to a stronger currency, say euros, the global economy will be subjected to an upheaval with unpredictable outcomes.

\section{Implications of peak oil scenarios}

The Hubbert-Campbell model (the resource logistic curve) is a very robust method for modelling future global oil production (Figures 2, 3). Conventional oil and gas are in decline as half the proven reserves have been burnt up over the past 140 years. All non-Middle East production is now at a maximum of its physical resource limits. If $\mathrm{M}-\mathrm{E}$ supplies are reduced, any shortfalls cannot be replaced by other sources. Even in the OPEC, resource limits will force production declines within 5-10 years. ${ }^{8}$ Remaining supplies will be consumed much faster due to increasing demands of the industrial world. A shift to natural gas is expected, but the global peak in gas production will also come within 20 years (Figure 2). Total gas reserves are $\sim 10$ trillion cu.feet SI units and half has been burnt off. The global peak for both oil and gas will come within the next 10 years. ${ }^{6-12}$ The Campbell Model ${ }^{6}$ predicts that once past the peak plateau, global production of conventional oil will decline at $\sim 2 \mathrm{Mb} / \mathrm{d}$ or $3 \%$ per year (see Figures $2 \& 3$ ). But annual increase of new demand is $\sim 3 \%$ and rising (BP). It will require at least $4 \mathrm{Mb} / \mathrm{d}$ of new supply each year to satisfy this demand, which is no longer available. The International Energy Administration (IEA) calculates that $\sim 19 \mathrm{Mb} / \mathrm{d}$ of nonconventional oil will be required by 2020 if demand is to be met. This is unlikely.
The problem with the $\mathrm{R} / \mathrm{P}$ ratios as a predictor is that it envisages a risk to oil supply difficulties only after 36 years. Campbell's Model uses peak production rates and calculates the decline thereafter (Figures $2 \& 3$ ). Here declining production is equated to the unsatisfied current demand, which is the key factor in future oil supplies. The world economy will have to come to terms with the rising oil prices. The current high prices are due to a combination of historically low prices, OPEC regional instability and rising demand in newly industrializing regions. Now is the time to tell the world that there is no more than 40 years of oil supplies left in the rocks and that most of this is in the M-E countries. Non-conventional oil cannot offset the conventional oil decline. If demand cannot be met, there will be rationing, inflation, recession and international tension as we have seen from time to time (e.g. the OPEC crisis in the late 1970s, Iran-Iraq War, Gulf War I and now the Iran crisis). The greatest challenge to the oil industry and governments is to cooperate in managing this decline in an orderly way. It has been estimated by the United Nations that without hydrocarbons enough food can be produced for only 2.5 billion people. Today the global population is $\sim 6$ billion; it will be 7.3 billion in 2050 .

The current production of $85 \mathrm{Mb} / \mathrm{d}$ may be at its limits. ${ }^{6-12}$ China alone will require $\sim 99 \mathrm{Mb} / \mathrm{d}$ by 2031 if it sustains its growth rate at $8-10 \%$. Obviously, such volumes will never be available and such growth rates near impossible due to the obvious supply constraints. Add India to this and there will surely be resource wars in the making. The permanent political tensions and instability in the OPEC have much to do with their large oil reserves. Access to these will determine who will dominate the scene. The Chinese leader on a state visit to Nigeria (27 $7^{\text {th }}$ April 2006) pledged to invest US\$ 4 billion in the energy sector, thereby making an entry into African oil, which has been traditionally controlled by the West. China needs the oil and the vast Nigerian market for its exports. Last year, the Chinese National Oil Company made a US $\$ 18$ billion bid for the US Oil Company UNOCAL, which was disallowed by the US Congress.

The view of some economists' is that the market will solve the energy problems. Accordingly the present crisis will produce an economic stimulus, which will discover new resources and invent new technologies that would maintain equilibrium in the markets and that regulations, which curtail economic growth are to be avoided. They do not say how growth can be maintained with a shrinking energy base. Globalization is a mechanism to gain open access to resources across the globe. 
Oil depletion is not a straightforward engineering problem. Technology only provides the infrastructure to run the oil and gas and is governed by the basic laws of physics. With a depleting energy base there is just not enough time to replace a fuel so cheap, abundant and versatile. Oil is rich in energy content, easy to use, store and transport. Oil and gas enabled us to operate highly complex systems on enormous scales. Nothing can replace it in time or scale. Most renewables and alternate fuels (wind, wave, solar, biofuels etc) are presently very marginal and also take a lot of energy and need the existing petroleum platform for future development (Figure 9). The non-conventional oil sector (oil shale, tar sands, coal gas etc) is still very far off. ${ }^{11}$

Solar energy provides only marginal net energy and photovoltaic cells (PVC) are built from hydrocarbon feed stocks. A global solar energy system would take over a hundred years to build and will require most of the steel production in the world. 5,9 Hydrogen fuel cells are not an energy source, but basically a form of energy storage. It requires energy to break the $\mathrm{H}-\mathrm{O}$ bond and release the $\mathrm{H}_{2}$. Every major component of PVC and hydrogen fuel cells will require hydrocarbon energy to fabricate. Oil cannot be replaced by a fuel cell economy. It will make an impact mainly in the automobile industry. Nuclear power plants are very expensive, takes 10 15 years to build and require a petroleum platform for all stages of construction, maintenance, extraction and processing of nuclear fuels. It is also a finite resource and has to live with the Chernobyl syndrome. But it could be a viable option in the future (Figure 9).

\section{DISCUSSION}

The present levels of production and consumption of petroleum are unsustainable. Petroleum resources are finite and non-renewable and there are technological limits to their extraction. Countries with $8-12 \%$ growth rates are doing so at the expense of dwindling resources. In a crisis, even the nuclear energy option would be on the cards. Countries will have to go for a mix of energy sources that suits them best, but reduce dependence on non-renewable options. Alternate technologies take time to develop and still require access to vast supplies of cheap oil and gas. Coal which is the only other fuel available in vast quantities, is not as efficient as oil and gas in energy conversion. It is unevenly distributed in the world (mainly in China, USA, USSR and Australia $-75 \%)$. These are high population countries, which will require it for their future use. Very little will be available to the rest of the world. Further, it will be going backwards technologically. Alternate energy sources can be developed, but will need a very long lag time to shift the world's entire industrial and transportation system from oil. This is not a doomsday scenario but a warning to be aware of the future directions and uncertainties in an energy hungry world.

So, what are the immediate alternatives? Firstly, enforceable conservation measures will buy us valuable time to enable the transition. Cutting down on wastage and transforming inefficient existing technologies and systems, better traffic control and mass transportation systems, better engine technology to improve consumption of oil are among the measures. Since transportation accounts for $65 \%$ of petroleum consumption, alternate technologies must come out of the labs and on to the streets quickly. The hard fact is that the world simply does not have the resources to sustain a population of 6 or 7 billion. It will be a technology mix eventually as no single energy source can replace oil (Figure 9). An attitudinal and culture shift away from profligate oil use is needed.

P.S. Readers of this article are advised to see the film Mad Max, which is about a society running out of oil and gas!

\section{Acknowledgement}

The author thanks the Editorial Board of the National Science Foundation for the invitation to write this article. He acknowledges Wikipedia, ASPO, WTRG Economics, Elsevier for the diagrams used in this article.

\section{References}

1. International Energy Agency. (2000). World Energy Outlook. IEA, Paris.

2. Deffeyes K.S. (2001). Hubbert's Peak. Princeton University Press, Princeton, New Jersey, USA.

3. North F.C. (1990). Petroleum Geology. Unwin and Hyman, Boston, Mass., USA. 631 pages.

4. Hatfield C.B. (1997). Oil back on the global agenda. Nature $387(6629): 121$.

5. British Petroleum Statistical Review of World Energy (2004).

6. Campbell C. J. (1996). The status of world oil depletion at the end of 1995. Energy Exploration and Exploitation 14(1), 63-81.

7. Campbell C.J. \& Laherrere J.H. (1995). The world's supply of oil, 1930-2050. Petroconsultants S.A., Geneva.

8. Bentley R.W.(2002). Global oil \& gas depletion: an overview. Energy Policy 30: 189- 205.

9. Deffeyes K.E. (2005). Beyond Oil: the view from Hubbert's peak. Princeton University Press, New Jersey, USA. www.princeton.edu/bubbert/.

10. Odell P. R.(1994). World oil resources, reserves and production. The Energy Journal (IAEE) 15, Special Issue, 89-114.

11. Perrodon A., Laherrere J.H. \& Campbell C.J. (1998). The world's non-conventional oil and gas. The Petroleum Economist Ltd (March), London.

12. Association for the Study of Peak Oil and Gas (ASPO) Newsletters (2003-2006). Also see www.peakoil.ie; wwr.peakoil.net; wwr.peakoil.com. 